\title{
Tensile Properties of Simulated Thin Slab Cast and Direct Rolled Low-carbon Steel Microalloyed with $\mathrm{Nb}, \mathrm{V}$ and $\mathrm{Ti}$
}

\author{
J. S. PARK, M. AJMAL ${ }^{1)}$ and R. PRIESTNER ${ }^{2)}$
}

Inchon Iron and Steel Co. Ltd, Inchon, Korea.

1) The Engineering University, Dept. of Metallurgical Engineering and Materials Science, Lahore, Pakistan.

2) University of Manchester/UMIST, Materials Science Centre, Grosvenor Street, Manchester M1 7HS, UK.

(Received on October 8, 1999; accepted in final form on December 21, 1999)

\begin{abstract}
The hot direct rolling of thin slab cast microalloyed, low-carbon steels was simulated on a laboratory scale. The carbon content of the steels ranged from 0.026 to $0.11 \mathrm{wt} \%$. In steels microalloyed with niobium, a significant loss of yield and tensile strength occurred when the carbon content exceeded approximately $0.07 \mathrm{wt} \%$. Large, eutectic NbCN precipitates, which formed during solidification, were observed at higher carbon contents. It was concluded that when the carbon content of the steel exceeded a critical level, segregation of niobium to the liquid phase during solidification of the castings resulted in the presence of the eutectic $\mathrm{NbCN}$. This effectively removed a significant fraction of the niobium from being able to participate in precipitation strengthening. The addition of up to $0.09 \mathrm{wt} \% \mathrm{~V}$, and of $\mathrm{V}$ plus up to $0.025 \mathrm{wt} \%$ $\mathrm{Ti}$, to steel containing $0.04 \mathrm{wt} \% \mathrm{Nb}$ failed to increase yield or tensile strength.
\end{abstract}

KEY WORDS: microalloyed steel; niobium; vanadium; titanium; thin-slab casting; hot direct rolling; tensile properties; eutectic precipitates.

\section{Introduction}

Microalloying additions are made to low carbon steels for a number of purposes. In the conventional controlled rolling of reheated slabs, an important function of niobium is to control recrystallisation in the austenite phase field in order to refine the ferrite grain size of the controlled rolled product. A second benefit is that niobium makes a contribution to the strength of the product through precipitation in the ferrite. Vanadium carbides and nitrides are too soluble in austenite to have a significant effect on grain refinement, when added to a Nb-bearing steel, but may augment precipitation strengthening, particularly at raised nitrogen levels. Titanium is generally added to restrain grain growth in the austenite on reheating and in the heat affected zone of welds, but is also capable of restraining recrystallisation in the austenite during controlled rolling, and of contributing to tensile strength.

In conventional processing of continuously cast thick slab, the steel is reheated to $1200-1250^{\circ} \mathrm{C}$ for up to $8 \mathrm{hr}$ before rolling. This conditions the austenite by partial homogenisation and solution of the microalloying elements. The austenite grain size after soaking and at the start of the rolling process is then usually smaller than it was in the original casting, being determined by the dispersion of any undissolved microalloy nitrocarbides and undissolved inclusions. In recent years, however, the practice of hot direct rolling has been developed, in which the as-cast austenite is rolled directly, without the intermediate stages of cooling to a low temperature, reheating and soaking. The austenite then has the coarse-grained, dendritic and segregated microstructure of the original casting prior to the commencement of hot rolling. Although hot direct rolling has been practised using conventional thick slab, its most practical application is in the production of hot rolled strip from thinner slab in minimills. With this newer technology, slab in thicknesses down to $50 \mathrm{~mm}$ is continuously cast and directly hot rolled within, typically, 15-20 min after casting; the only "heat treatment" between casting and rolling is temperature equalisation at approximately $1100-1150^{\circ} \mathrm{C}$ during that time interval.

Both niobium and titanium segregate to the liquid phase during freezing, to form eutectic carbonitrides or nitrides on solidification. ${ }^{1-5)}$ In the absence of a prolonged soaking period at high temperature, it might be expected that the presence of such precipitates in the austenite at the commencement of direct hot rolling might reduce the effectiveness of the microalloying additions, compared to their effect in conventional processing. The purpose of this research, therefore, was to investigate the tensile properties of hot direct rolled low carbon steels microalloyed with niobi$\mathrm{um}$, the composition being varied to allow eutectic $\mathrm{NbCN}$ to form over part of the range. The effect of including $\mathrm{V}$ and $\mathrm{Ti}$ additions over part of the composition range was also investigated.

\section{Experimental Details}

The experimental technique used for simulating the hot direct rolling of as-cast austenite has been described else- 
where. $^{3,6)}$ In summary, approximately $1 \mathrm{~kg}$ of steel of each required composition was made by induction melting under 300 mbar of argon. A reusable mould assembly consisted of a mould made of aluminous refractory wrapped in an insulating blanket of aluminosilicate fibre. The mould was preheated to $1050^{\circ} \mathrm{C}$ and the fibrous blanket to $250^{\circ} \mathrm{C}$ before use. A quartz thermocouple tube was incorporated on the centre line of the casting. The molten steel was poured into the hot mould to produce an ingot $15 \mathrm{~mm}$ thick, $75 \mathrm{~mm}$ wide and approximately $150 \mathrm{~mm}$ long. The temperature of the mould and its insulation was such that the cooling rate on the centre line of the ingot was approximately $2 \mathrm{~K} / \mathrm{s}$ between the temperatures of $1400^{\circ} \mathrm{C}$ and $1200^{\circ} \mathrm{C}$, and the secondary dendrite arm spacing was approximately $150 \mu \mathrm{m}$. These parameters are similar to those expected in thin slab casting. ${ }^{7}$ )

After casting, the mould assembly was transferred to the rolling mill and the temperature of the ingot was monitored. As the temperature approached the required temperature of the first pass the ingot was extracted from the mould and presented to the rolls. The ingot was then rolled to $4 \mathrm{~mm}$ thickness in three passes. The reductions in each successive pass were $43 \%, 35 \%$ and $27 \%$. The interpass time interval was determined by the time needed to reverse the mill and screw down the rolls, which was $25 \mathrm{sec}$. Two sets of rolling temperatures were used:

(a) 1st pass $1200^{\circ} \mathrm{C}$; 2nd pass $1100^{\circ} \mathrm{C}$; 3rd pass $1000^{\circ} \mathrm{C}$, and

(b) $1 \mathrm{st}$ pass $1140^{\circ} \mathrm{C}$; 2nd pass $1050^{\circ} \mathrm{C}$; 3rd pass $950^{\circ} \mathrm{C}$

The total reduction of $73 \%$ would correspond to the practical rolling of $50-80 \mathrm{~mm}$ thick slab to $13.5-22 \mathrm{~mm}$ thickness. In order to simulate approximately the cooling of material in that range of thickness, the rolled plates were cooled between blankets of aluminosilicate fibre, the average cooling rate between $850^{\circ} \mathrm{C}$ and $700^{\circ} \mathrm{C}$ being $0.5 \mathrm{~K} / \mathrm{s}$.

These differences in rolling temperatures affected the ferrite grain size: After rolling at the higher temperatures the average grain size was $11 \pm 0.9 \mu \mathrm{m}$, and after rolling at the lower temperatures the average grain size was $8 \pm$ $1.1 \mu \mathrm{m}$. Some ingots were not rolled, but were extracted from the mould assembly at $1400^{\circ} \mathrm{C}$ and immediately quenched into iced brine. These ingots were examined metallographically in order to establish whether eutectic niobium-carbonitride had formed during freezing.

The compositions of the castings are listed in Table $\mathbf{1 .}$ $\mathrm{Mn}$ and Si contents were kept as constant as possible, at approximately $1.3 \mathrm{wt} \% \mathrm{Mn}$ and $0.25 \mathrm{wt} \% \mathrm{Si}$. Casts $1-4$ were a series of increasing carbon content in which a constant addition of approximately $0.03 \mathrm{wt} \% \mathrm{Nb}$ was added. Casts 5-8 were a similar series of increasing carbon content, but at a higher niobium content of $0.04 \mathrm{wt} \%$. Vanadium was added to casts $9-11$, and vanadium and titanium to casts $12-14$. Casts which were quenched after solidification instead of being rolled are labelled "Q", and the casts which were rolled at the higher rolling temperatures are labelled with an asterisk in Table 1.

Tensile bars having a gauge length of $25 \mathrm{~mm}$, a width of $10 \mathrm{~mm}$ and $2.8-3 \mathrm{~mm}$ thick were machined in the longitudinal direction of the rolled plate, and tested at a crosshead speed of $0.5 \mathrm{~mm} / \mathrm{min}$. The tensile properties that are report-
Table 1. Compositions of the steels.

\begin{tabular}{|c|c|c|c|c|c|c|c|c|c|}
\hline & Cast & $\mathrm{C}$ & $\mathrm{Si}$ & $\mathrm{Mn}$ & $\mathrm{P}$ & $\mathrm{S}$ & $\mathrm{Nb}$ & $\mathrm{V}$ & $\mathrm{Ti}$ \\
\hline \multirow{5}{*}{$0.03 \mathrm{wt} \% \mathrm{Nb}$} & $1^{*}$ & 0.028 & 0.23 & 1.22 & 0.004 & 0.005 & 0.031 & - & - \\
\cline { 2 - 11 } & $2^{*}$ & 0.043 & 0.26 & 1.30 & 0.003 & 0.005 & 0.032 & - & - \\
\cline { 2 - 11 } & $3^{*}$ & 0.064 & 0.25 & 1.27 & 0.004 & 0.005 & 0.032 & - & - \\
\cline { 2 - 11 } & $4^{*}$ & 0.098 & 0.26 & 1.31 & 0.005 & 0.004 & 0.030 & - & - \\
\hline \multirow{5}{*}{$04 \mathrm{wt} \% \mathrm{Nb}$} & $5^{*}$ & 0.026 & 0.23 & 1.29 & 0.006 & 0.003 & 0.039 & - & - \\
\cline { 2 - 11 } & 6 & 0.04 & 0.26 & 1.34 & 0.013 & 0.007 & 0.042 & - & - \\
\cline { 2 - 10 } & $7^{*}$ & 0.07 & 0.24 & 1.34 & 0.008 & 0.005 & 0.042 & - & - \\
\cline { 2 - 10 } & $8^{*}$ & 0.11 & 0.24 & 1.29 & 0.005 & 0.006 & 0.039 & - & - \\
\hline \multirow{5}{*}{ Nb-V Steels } & 9 & 0.05 & 0.26 & 1.34 & 0.012 & 0.008 & 0.042 & 0.09 & - \\
\cline { 2 - 10 } & 10 & 0.066 & 0.25 & 1.22 & 0.012 & 0.011 & 0.042 & 0.02 & - \\
\cline { 2 - 10 } & 11 & 0.088 & 0.22 & 1.24 & 0.013 & 0.013 & 0.042 & 0.034 & - \\
\hline \multirow{3}{*}{ Quenched } & 12 & 0.05 & 0.29 & 1.38 & 0.013 & 0.009 & 0.042 & 0.02 & 0.025 \\
\cline { 2 - 10 } & 13 & 0.055 & 0.27 & 1.36 & 0.013 & 0.008 & 0.042 & 0.09 & 0.025 \\
\cline { 2 - 10 } & 14 & 0.062 & 0.24 & 1.2 & 0.011 & 0.009 & 0.042 & 0.02 & 0.007 \\
\hline & $13 \mathrm{Q}$ & 0.08 & 0.26 & 1.31 & 0.009 & 0.009 & 0.033 & - & - \\
\cline { 2 - 10 } & $14 \mathrm{Q}$ & 0.049 & 0.27 & 1.26 & 0.009 & 0.007 & 0.041 & - & - \\
\cline { 2 - 9 } & $15 \mathrm{Q}$ & 0.12 & 0.22 & 1.19 & 0.008 & 0.008 & 0.033 & - & - \\
\cline { 2 - 9 } & $16 \mathrm{Q}$ & 0.12 & 0.25 & 1.25 & 0.01 & 0.007 & 0.040 & - & - \\
\hline
\end{tabular}

$\mathrm{O}_{2}<0.008 \mathrm{wt} \% ; \mathrm{N}_{2}<0.005 \mathrm{wt} \%$.

Table 2. Tensile properties and ferrite grain sizes.

\begin{tabular}{|c|c|c|c|c|}
\hline & Cast & $\begin{array}{l}\text { Yield Strength } \\
(\mathrm{MPa})\end{array}$ & $\begin{array}{c}\text { Tensile Strength } \\
\text { (MPa) }\end{array}$ & Grain size $(\mu \mathrm{m})$ \\
\hline \multirow{4}{*}{$0.03 w t \% \mathrm{Nb}$} & 1 & 334 & 418 & 11.8 \\
\hline & 2 & 340 & 430 & 11.9 \\
\hline & 3 & 350 & 448 & 10.2 \\
\hline & 4 & 327 & 447 & 11.8 \\
\hline \multirow{4}{*}{$0.04 w t \% \mathrm{Nb}$} & 5 & 333 & 406 & 10.5 \\
\hline & 6 & 375 & 450 & 8.6 \\
\hline & 7 & 389 & 481 & 9.6 \\
\hline & 8 & 351 & 466 & 10.8 \\
\hline \multirow{3}{*}{$\mathrm{Nb}-\mathrm{V}$ Steels } & 9 & 390 & 473 & 8.3 \\
\hline & 10 & 390 & 467 & 6.8 \\
\hline & 11 & 390 & 470 & 7.2 \\
\hline \multirow{3}{*}{ Nb-V-Ti Steels } & 12 & 376 & 455 & 10.3 \\
\hline & 13 & 378 & 470 & 7.8 \\
\hline & 14 & 375 & 470 & 7.7 \\
\hline
\end{tabular}

ed are the averages of two or three tests. Metallographic specimens were taken from rolled plates in the long-transverse orientation, and etched in nital. Ferrite grain sizes were determined by the mean linear intercept method, in which the number of intersections of grains with a circle superimposed on at least 10 fields of view were counted, and the mean linear intercept was corrected for the volume fraction of pearlite. Quenched ingots were deeply etched and examined by scanning electron microscopy to establish whether a eutectic carbonitride had formed during freezing. Carbon extraction replicas were also taken from quenched ingots to examine the eutectic precipitate in more detail using transmission electron microscopy.

\section{Results and Discussion}

Tensile properties of the rolled plates are reported in Table 2, together with ferrite grain sizes. The ductility parameters of uniform and total elongation were $21.5 \pm 1.2 \%$ and $38 \pm 2.2 \%$, respectively, and showed no significant dependence on composition, rolling temperature or carbon content. Yield stress is plotted against carbon content in Fig. 1 and ultimate tensile strength is plotted in Fig. 2.

\subsection{Tensile Results for Nb-only Steels}

At both levels of niobium content the yield strength and the UTS increased initially with increasing carbon content, to maximum values at $0.06-0.07 \mathrm{wt} \% \mathrm{C}$. The yield stress 


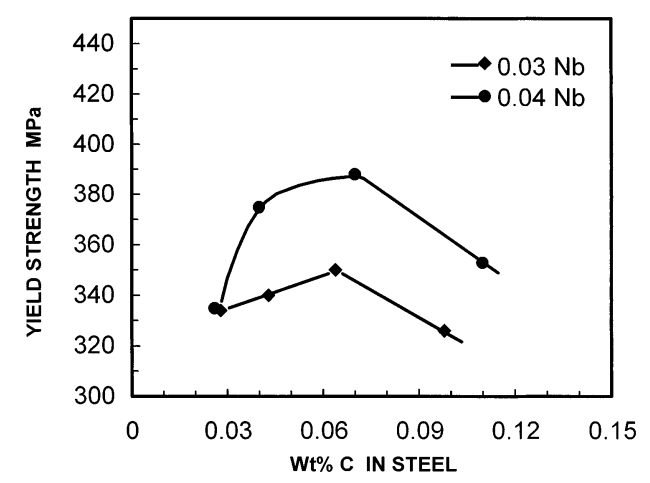

Fig. 1. Yield stress as a function of carbon content for the Nbsteels.

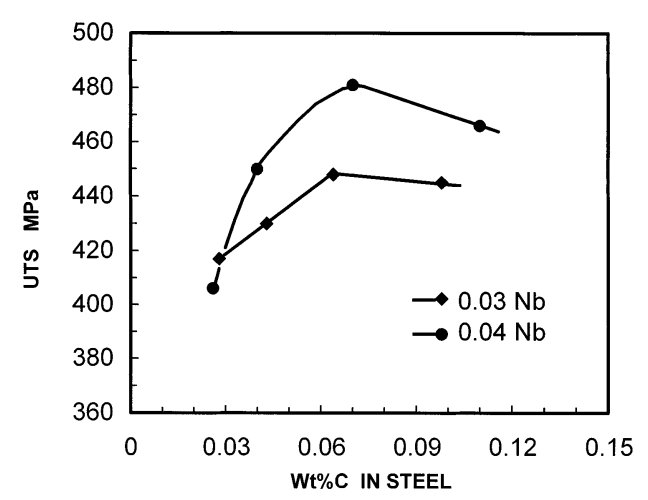

Fig. 2. Ultimate Tensile Strength as a function of carbon content for the Nb-steels.

was strongly reduced at higher carbon contents, while the UTS fell less strongly. At the lowest carbon contents, increasing the $\mathrm{Nb}$ content from $0.03 \mathrm{wt} \%$ to $0.04 \mathrm{wt} \%$ had virtually no effect on strength, but with increasing carbon content the extra $\mathrm{Nb}$ raised both yield and UTS.

The yield strength of low carbon ferrite/pearlite steel containing $\mathrm{Mn}$ and $\mathrm{Si}$ as the solid solution strengthening elements may be expressed as ${ }^{8)}$ :

$$
\begin{aligned}
\text { Yield Strength }(\mathrm{MPa})= & 88+37(\mathrm{wt} \% \mathrm{Mn})+83(\mathrm{wt} \% \mathrm{Si}) \\
& +15.1\left(d^{-1 / 2}\right) \ldots \ldots \ldots \ldots \ldots \ldots \ldots \ldots \ldots \ldots \ldots \ldots \ldots \ldots \ldots
\end{aligned}
$$

where $d$ is ferrite grain size (mean linear intercept in $\mathrm{mm}$ ). In microalloyed steels, precipitation of microalloy carbides, nitrides or carbonitrides in ferrite also contributes to yield strength. The difference between the measured yield strength and the value predicted by Eq. (1) can, therefore, be interpreted as being the specific contribution of precipitation strengthening to the observed yield strength. This precipitation strengthening contribution was calculated, using Eq. (1) and the compositional, grain size and observed yield strength data in Tables 1 and 2, and is plotted against carbon content in Fig. 3.

In the case of the $0.03 \mathrm{wt} \% \mathrm{Nb}$ steels, the precipitation hardening contribution is approximately constant with carbon content up to $0.07 \mathrm{wt} \% \mathrm{C}$, and then falls to a lower value at the highest carbon level. In the case of the $0.04 \mathrm{wt} \% \mathrm{Nb}$ steels, the precipitation hardening component is about the same as for the lower level of $\mathrm{Nb}$ at the lowest carbon content, increases with increasing carbon, and then also falls to a lower value at the highest carbon content. It is concluded that the effectiveness of the microalloying addi-

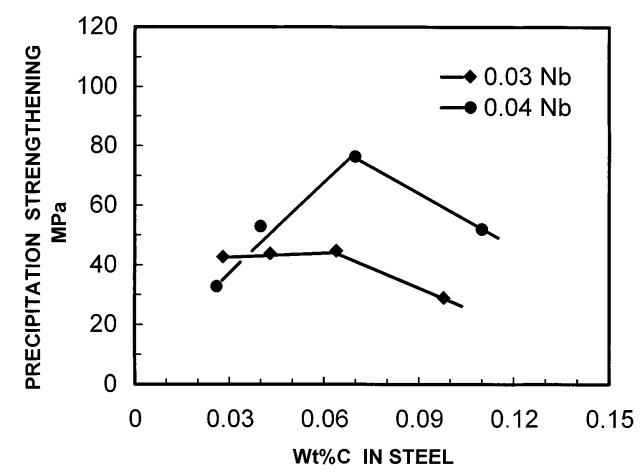

Fig. 3. The precipitation strengthening component of the yield strength for the $\mathrm{Nb}$-steels.

tion was sharply reduced when the carbon content of the steel exceeded a critical level of approximately $0.07 \mathrm{wt} \%$.

The increase of UTS with carbon content at low carbon contents (Fig. 2) is partly due to increasing pearlite volume fraction and partly to precipitation strengthening. Again, the significant feature is that the strength stops increasing, and indeed decreases slightly at the highest carbon contents.

The processing of some $0.04 \mathrm{wt} \% \mathrm{C}$ specimens was interrupted after two passes by quenching, and carbon extraction replicas were examined by transmission electron microscopy. $\mathrm{NbC}$ precipitates approximately $5 \mathrm{~nm}$ in size were observed, in arrays that indicated that they were strain-induced precipitates on dislocation substructure in the austenite. No differences were observed in these strain-induced precipitates in specimens containing more and less than the critical carbon content, above which the strength was reduced. Such precipitates, formed in austenite prior to transformation, can not contribute to the strengthening of the ferrite formed during cooling. The amount of precipitation strengthening of ferrite depends on cooling rate, which was constant, and the concentration of niobium still in solution in the austenite at the end of rolling. The principal cause of the loss of strength at the higher carbon contents is, therefore, ascribed to the presence of eutectic carbonitrides in the as-cast austenite, as discussed in the following.

\subsection{Formation of Eutectic $\mathrm{NbCN}$}

Casts of $0.03 \mathrm{wt} \% \mathrm{Nb}$ and $0.04 \mathrm{wt} \% \mathrm{Nb}$ steels with carbon contents near the peak in yield strength were made and quenched from $1400^{\circ} \mathrm{C}$. These were casts $13 \mathrm{Q}$ and $14 \mathrm{Q}$. No eutectic niobium carbonitrides could be detected by scanning electron microscopy nor by transmission electron microscopy of extracted replicas.

Casts 15Q and 16Q were quenched casts of the $0.03 \mathrm{wt} \%$ $\mathrm{Nb}$ and $0.04 \mathrm{wt} \% \mathrm{Nb}$ steels at the higher carbon levels, at which the yield strength was sharply reduced. Many large, eutectic carbonitride precipitates were found in these quenched castings. Figure 4(a) is a scanning electron micrograph of such a precipitate in Cast 15Q. The precipitate was present at a prior austenite grain corner and was associated with microporosity. Figure 4(b) is a transmission electron micrograph of a particle extracted on a carbon replica. The niobium carbonitride particle consisted of a thin film which tended to subdivide into parallel lamellae or rods. The rounded black particle with which it was associated was manganese sulphide. MnS was often also present as 


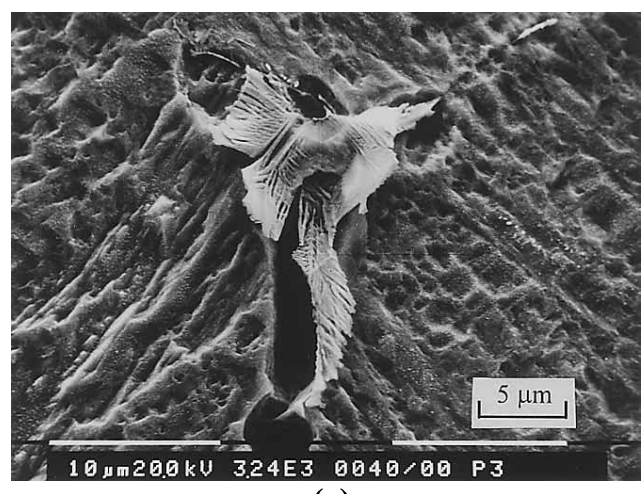

(a)

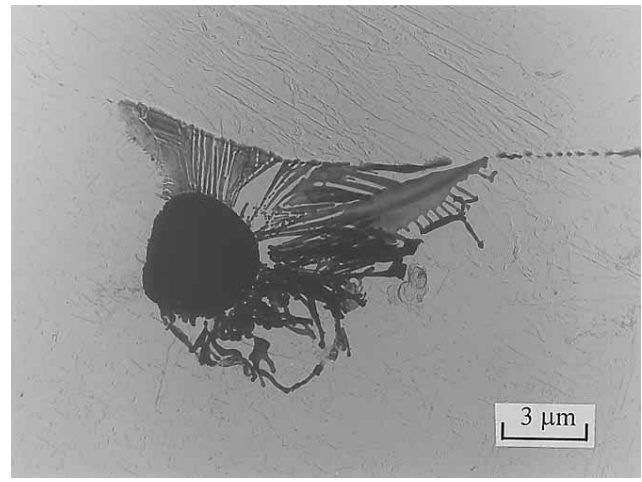

(b)

Fig. 4. Eutectic niobium carbonitride precipitates in higher-carbon $\mathrm{Nb}$-steels quenched from $1400^{\circ} \mathrm{C}$.

(a) Steel 15Q, SEM micrograph; (b) Steel 16Q, TEM micrograph of extraction replica.

small nodules on the ends of individual rods, and was often detected as a thin coating on $\mathrm{NbCN}$ rods or lamellae. All these characteristics suggest that the $\mathrm{NbCN}$ formed eutectically, along with $\mathrm{MnS}$, during the final stage of solidification. The equilibrium solution temperatures of $\mathrm{NbCN}$ in the austenites of steels 15Q and 16Q were calculated to be $1184^{\circ} \mathrm{C}$ and $1211^{\circ} \mathrm{C}$, respectively, using the solubility product proposed by Irvine et al. ${ }^{9)} ; \log [\mathrm{Nb}][\mathrm{C}+12 \mathrm{~N} / 14]=$ $2.26-6770 / T$, where $T$ is temperature $(\mathrm{K})$. The presence of these eutectic precipitates is, therefore, a strongly non-equilibrium feature, and must have occurred as a result of segregation of $\mathrm{Nb}$, along with $\mathrm{Mn}$ and $\mathrm{S}$, to the liquid phase during freezing.

Clearly, increasing the carbon content of the steel above a critical level caused the precipitation of eutectic carbonitride during solidification. It follows that the concentration of niobium remaining in solid solution, and which would contribute to precipitation strengthening of the ferrite, was reduced at carbon contents above the critical level. A rough estimate of the fraction of the total niobium content used up in forming the eutectic may be made as follows.

Elementary theory of segregation during freezing in a system in which there is no diffusion of the segregating solute species in the solid phase and complete mixing in the liquid phase suggests that the solute concentration in the liquid fraction, $C_{\mathrm{L}}$, is given by ${ }^{10)}$

$$
C_{\mathrm{L}}=C_{0} \cdot f_{\mathrm{L}}^{(k-1)}
$$

where $C_{0}$ is the average concentration of solute in the alloy, $f_{\mathrm{L}}$ is the liquid volume fraction and $k$ is the distribution coefficient of the solute between the solid and liquid phases.
Assuming that the steel solidifies initially as $\delta$-ferrite and the appropriate value of $k$ for niobium is $0.03,{ }^{11)}$ and that final eutectic solidification occurs when the liquid volume fraction has shrunk to $5 \%$, then, the concentration of niobium in the eutectic liquid of a $0.04 \mathrm{wt} \% \mathrm{Nb}$ steel will be $0.33 \mathrm{wt} \% \mathrm{Nb}$. The fraction of the total niobium content of the steel present in the liquid will be approximately $41 \%$, and the average concentration of $\mathrm{Nb}$ remaining in solid solution in the solid fraction will be $0.025 \mathrm{wt} \%$.

This estimate of the fraction of the total niobium consumed in forming the eutectic is subject to several uncertainties. For example, the liquid fraction at the moment of eutectic freezing is unknown; however, varying $f_{\mathrm{L}}$ from $3 \%$ to $10 \%$ only changes the fraction of niobium consumed in the eutectic from $35 \%$ to $50 \%$. Also, it should be expected that some diffusion of niobium would occur in the solid, which would reduce the amount of niobium segregating to the eutectic. Nevertheless, the calculation serves to demonstrate that the concentration of niobium in solid solution prior to hot direct rolling will be significantly reduced by the formation of the eutectic. As shown in Figs. 1 and 3, the yield strength, and the precipitation strengthening contribution to the yield strength, of the $0.04 \mathrm{wt} \% \mathrm{Nb}$ steel dropped, when the eutectic carbonitride formed at the highest carbon content, almost to that of the $0.03 \mathrm{wt} \% \mathrm{Nb}$ steel at lower carbon contents. It may be deduced from this evidence, therefore, that nearly $25 \%$ of the total $\mathrm{Nb}$ had been lost to the eutectic $\mathrm{NbCN}$.

\subsection{Effect of Adding Vanadium and Titanium}

The carbides and nitrides of niobium, vanadium and titanium are isomorphous and mutually intersoluble. Consequently, when two or more of the microalloying elements are present in steel, the equilibrium stoichiometric precipitate will be a mixed carbonitride of general formula $\left(\mathrm{Ti}_{x} \mathrm{Nb}_{v} \mathrm{~V}_{1-x-v}\right)\left(\mathrm{C}_{y} \mathrm{~N}_{1-y}\right)$. Following the method proposed by Hillert and Staffanson, ${ }^{12)}$ many authors have performed thermodynamic calculations of the composition of mixed carbonitrides in equilibrium with their solid solution in austenite, from a knowledge of the solubility products of the individual carbides and nitrides. These include calculations by one of the present authors and co-workers ${ }^{1,3,13,14)}$ for austenite in the composition range $0-0.22 \mathrm{wt} \% \mathrm{C}, 0$ $0.015 \mathrm{wt} \% \mathrm{~N}, 0-0.05 \mathrm{wt} \% \mathrm{Nb}, 0-0.038 \mathrm{wt} \% \mathrm{Ti}$, and $0-$ $0.011 \mathrm{wt} \% \mathrm{~V}$. The vanadium content is higher in the steels used in the present study: however, higher vanadium contents were included in calculations by Adrian and Pickering, ${ }^{15)}$ Rios $^{16)}$ and Rios and de Avillez ${ }^{17)}$ in $\mathrm{Nb}-\mathrm{V}$ austenite, and by Zou and Kirkaldy ${ }^{18)}$ in $\mathrm{Nb}-\mathrm{Ti}-\mathrm{V}$ austenite.

The thermodynamic calculations indicate that, for the $\mathrm{Nb}-\mathrm{V}$ compositions used here (steels 9-11) the equilibrium precipitate in austenite should be richer in $\mathrm{V}$ and $\mathrm{C}$ at low temperatures and richer in $\mathrm{Nb}$ and $\mathrm{N}$ at higher temperatures. However, the $(\mathrm{NbV})(\mathrm{CN})$ precipitates should be completely dissolved in the austenite after solidification.

In the case of the $\mathrm{Nb}-\mathrm{V}-\mathrm{Ti}$ compositions (steels 12-14), the thermodynamic calculations indicate that at equilibrium a small volume fraction of precipitate should be present in the austenite after solidification. At high temperatures in the austenite phase field the equilibrium precipitate should 

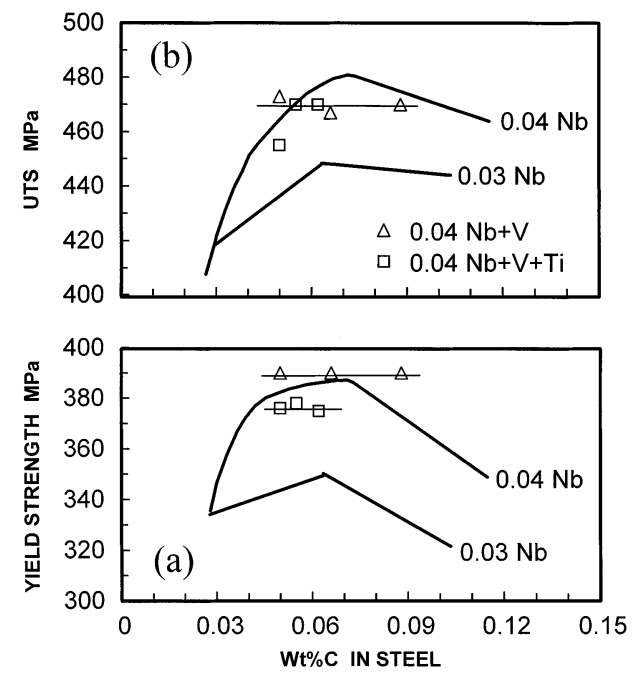

Fig. 5. Effect of adding vanadium and titanium to $0.04 \mathrm{wt} \% \mathrm{Nb}$ steel on; (a) the yield strength, and (b) the ultimate tensile strength.

be almost entirely TiN. At lower temperatures the equilibrium precipitate becomes richer in $\mathrm{Nb}$ and $\mathrm{C}$, and $\mathrm{V}$ becomes a significant component in the equilibrium precipitate as the temperature falls below approximately $1000^{\circ} \mathrm{C}$.

The results of equilibrium calculations need to be applied with some caution. The composition of very small precipitates, at nucleation and during the earliest stage of growth, are affected by capillarity and the diffusional kinetics of the precipitating species. ${ }^{17,18)}$ In $\mathrm{Nb}-\mathrm{V}^{17)}$ and $\mathrm{Nb}-\mathrm{Ti}^{18)}$ austenites, the $\mathrm{Nb}$ concentration in fine $(\mathrm{NbV})(\mathrm{CN})$ and $(\mathrm{NbTi})(\mathrm{CN})$ precipitates was found to be higher than predicted by equilibrium thermodynamic calculations. These factors can lead to compositional coring in the precipitates as they grow, ${ }^{18)}$ especially when precipitation progresses with falling temperature. ${ }^{4)} \mathrm{Li}$ et al. ${ }^{1)}$ and Priestner et al. ${ }^{14)}$ also showed that the initial precipitates that formed at all temperatures in $\mathrm{Nb}-\mathrm{Ti}-\mathrm{V}$ austenite contained a higher concentration of $\mathrm{Nb}$ than predicted at equilibrium, and that the composition of the precipitates only approached, but did not reach, equilibrium even after $24 \mathrm{hr}$ at temperature. Zhou and Priestner ${ }^{3)}$ have shown that TiN precipitates present in a cast at high temperatures can acquire a coating of $\mathrm{Nb}$-rich carbonitride as the cast cools. Kejian and Baker ${ }^{19)}$ have also shown that TiN precipitates formed at high temperatures can act as nucleants for $\mathrm{Nb}$-rich precipitates at lower temperatures, in preference to the compositional change needed to form a single precipitate of the equilibrium composition.

Additions of vanadium were made to steels 9-11, Table 1 , and of both vanadium and titanium to steels $12-14$, at the $0.04 \mathrm{wt} \% \mathrm{Nb}$ level and at carbon contents close to that at which the maximum yield strength of the $0.04 \mathrm{wt} \% \mathrm{Nb}$ steel was observed. The effect of these additions on yield and tensile strength are shown in Fig. 5. These steels were rolled at the lower temperatures and had the slightly finer average grain size, which should have contributed, on average, approximately $25 \mathrm{MPa}$ to the yield strength. It is clear, therefore, that these additions did not raise the yield strength, and, in fact, reduced the precipitation strengthening effect of the niobium.

The ineffectiveness of the vanadium addition is almost certainly due to the low nitrogen content of the steels. Lubensky et $a l .^{20)}$ found it necessary to increase the nitrogen content of hot direct rolled, thin slab cast steel to $0.015-0.02 \mathrm{wt} \% \mathrm{~N}$ in order to fully utilise the precipitation strengthening effect of vanadium additions of approximately $0.1 \mathrm{wt} \% \mathrm{~V}$. Another factor is that when niobium and vanadium are both present, the stable microalloy precipitate in austenite would be the mixed microalloy carbonitride, $(\mathrm{NbV})(\mathrm{CN})$, having a lower solubility than $\mathrm{Nb}(\mathrm{CN})$ itself. Therefore, more strain-induced precipitation may be expected in the austenite during rolling than if the vanadium were not present. This, in turn, could reduce the amount of niobium available for precipitation in the ferrite.

The effect of titanium in reducing the yield strength of $\mathrm{Nb}$-steels has also been noted elsewhere. ${ }^{19,21,22)}$ Crowther and Morrison $^{22}$ reported the average yield and tensile strengths of a very large number of commercially produced, conventionally controlled rolled $\mathrm{Nb}$ and $\mathrm{Nb}-\mathrm{Ti}$ steels as a function of plate thickness. For plate of $20 \mathrm{~mm}$ thickness, as simulated approximately by the cooling rate used here after rolling, the yield and tensile strengths were $380 \mathrm{MPa}$ and $490 \mathrm{MPa}$, very close to the maximum values reported here for the $0.04 \mathrm{wt} \% \mathrm{Nb}$ steel of the optimum carbon content. They also reported that the strength loss on adding titanium to the niobium steels was $20 \mathrm{MPa}$, for both yield and tensile strength. The reason for the loss of strength on adding titanium to $\mathrm{Nb}$-steels may be that titanium segregates even more strongly than niobium during solidification. ${ }^{1,23)}$ It is possible that TiN formed first in austenite, either during solidification or before rolling commenced. These precipitates may then have acted as heterogeneous nucleation sites for the precipitation of $\mathrm{NbC}$. Kejian and $\mathrm{Baker}^{19)}$ observed such compound precipitates, consisting of hemispherical caps or radiating spikes of $\mathrm{NbC}$ which had formed on TiN cubes, in conventionally controlled rolled $\mathrm{Nb}-\mathrm{Ti}$ steels. They estimated that enough niobium was used in this precipitation phenomenon to explain the loss of yield strength observed when titanium was added to $\mathrm{Nb}$-steel. Nakahara ${ }^{24)}$ also noted a loss of yield strength when $\mathrm{Nb}$ was added to a Ti-steel, which was explained in terms of the presence of larger, mixed (TiNb)C precipitates after processing.

The most significant result from the present research is that raising the carbon content of $\mathrm{Nb}$-containing steel led to a significant loss of strength, and this is likely to be true in the presence of additional microalloying elements, of vanadium and titanium. Lubensky et al. ${ }^{20)}$ have described the commercial development of steel chemistries for the hot direct rolling of thin slab HSLA steels of $550 \mathrm{MPa}$ yield strength. With a finishing temperature of $865^{\circ} \mathrm{C}$ to obtain a ferrite grain size of $5 \mu \mathrm{m}$ and additions of up to $0.035 \mathrm{wt} \%$ $\mathrm{Nb}, 0.09 / 0.11 \mathrm{wt} \% \mathrm{~V}$ and $0.007 / 0.013 \mathrm{wt} \% \mathrm{Ti}$, and a high nitrogen content of $0.015 / 0.02 \mathrm{wt} \%$ to boost precipitation of $\mathrm{VN}$, low strength properties were obtained when the carbon level was $0.13 / 0.15 \mathrm{wt} \% \mathrm{C}$. However, reducing the carbon content to a maximum level $0.07 \mathrm{wt} \%$ allowed achievement of the $550 \mathrm{MPa}$ yield strength. This experience from commercial practice is consistent with the results presented here for laboratory-simulated hot direct rolling of thin slab. On the basis of the present results, it can be suggested that at the higher carbon contents a significant fraction of the niobium was lost, due to segregation to the liquid phase during 
solidification and the formation of eutectic niobium carbonitride. This led to the loss of some of the precipitation strengthening effect of the niobium addition, which was restored by lowering the carbon content to a level at which the eutectic $\mathrm{NbCN}$ did not form.

\section{Summary and Conclusions}

The hot direct rolling of thin slab cast, low-carbon steels microalloyed with niobium, vanadium and titanium was simulated on a laboratory scale. The carbon content of the steels was varied from 0.026 to $0.11 \mathrm{wt} \%$. There was a significant loss of yield strength and a smaller loss of tensile strength in the $\mathrm{Nb}$-steels when the carbon content was increased above a critical level of approximately $0.07 \mathrm{wt} \% \mathrm{C}$.

Eutectic NbCN precipitates were observed in steels containing the higher carbon contents, but not at lower carbon contents. It was concluded that when the carbon content of the steel exceeded a critical level, segregation of niobium to the liquid phase during solidification of the castings resulted in the presence of the $\mathrm{NbCN}$ eutectic particles. This effectively removed a significant fraction of the niobium from being able to participate in precipitation strengthening of the ferrite.

The addition of vanadium alone and vanadium and titanium together to steel containing $0.04 \mathrm{wt} \% \mathrm{Nb}$ failed to increase yield or tensile strength, and appeared to reduce slightly the precipitation strengthening contribution to the yield strength.

\section{Aknowledgements}

M. Ajmal is grateful to the Association of Commonwealth Universities for a Fellowship tenable at the Manchester Materials Science Centre during the period of the research. J. S. Park is grateful for a Chevenings S and $\mathrm{T}$ Award and a University of Manchester Research Scholarship.

\section{REFERENCES}

1) P. H. Li, A. K. Ibraheem and R. Priestner: Proc. Int. Conf. on Microalloying in Steel, ed. by J. M. R. Rodrignez Ibabe et al., Trans.
Tech. Publications, Zurich (1998), 95-102.

2) Z. Chen, M. H. Loretto and R. C. Cochrane: Mater. Sci. Technol., 3 (1987), 836-844.

3) C. Zhou and R. Priestner: ISIJ Int., 36 (1996), 1397-1405.

4) D. C. Houghton, G. C. Weatherly and J. D. Embury: The Thermomechanical Processing of Microalloyed Austenite, ed. by A. J. DeArdo et al., The Metallurgical Society, AIME, Warrendale, PA, (1981), 267-292.

5) S. V. Subramanian and H. Zou: Proc. of Int. Conf. On Processing, Microstructure and Properties of Micro-alloyed and Other Modern HSLA Steels, ISS, Warrendale, PA, (1992), 23-31.

6) R. Priestner and C. Zhou: Ironmaking Steelmaking, 22 (1995), 326-332.

7) O. Dremailova, M. T. Shehata and E. Es-Sadiqi: Microstructural Science, 26, (1999), 481-485.

8) T. Gladman, D. Dulieu and I. D. McIvor: "Microalloying '75", Union Carbide Corp., Buffalo, New York (1977), 32-55.

9) K. J. Irvine, F. B. Pickering and T. Gladman: JISI, 205 (1967), 161.

10) D. A. Porter and K. E. Easterling: Phase Transformations in Metals and Alloys, 2nd Ed., Chapman and Hall, London, (1992), 212.

11) V. K. Heikkinen and R. H. Packwood: Scand. J. Metall., 6 (1977), 170.

12) M. Hillert and L. I. Staffansson: Acta. Chem. Scand., 24 (1970), 3618-26.

13) R. Priestner, C. Zhou and A. K. Ibraheem: Titanium Technology in Microalloyed Steels, ed. by T. N. Baker, IOM, London, (1997), $150-168$.

14) R. Priestner, P. H. Li, C. Zhou and A. K. Ibraheem: Microstructural Science, 26, (1999), 447-454.

15) H. Adrian and F. B. Pickering: Mater. Sci. Technol., 7 (1991), 176182.

16) P. R. Rios: J. Mater. Sci. Eng., A, 142 (1991), 87-94.

17) P. R. Rios and R. R. deAvillez: J. Mater. Sci. Eng. A, 160 (1993), 101-106.

18) H. Zou and J. S. Kirkaldy: Metall. Trans. A, 22A, (1991), 15111524.

19) H. Kejian and T. N. Baker: Titanium Technology in Microalloyed Steels, ed. by T. N. Baker, IOM, London, (1997), 115-132.

20) P. J. Lubensky, S. L. Wigman and D. J. Johnson: Proc. Int Conf. Microalloying '95, ISS, Warrendale, PA, (1995), 225-233.

21) A. C. Kneissel, G. Posch, C. I. Garcia and A. J. deArdo: Proc. Int. Symp. on Low-Carbon Steels for the '90's, ed. by R. Asfahani and G. Tither, TMS, Warrendale PA, (1993), 113-119.

22) D. N. Crowther and W. B. Morrison: Titanium Technology in Microalloyed Steels, ed. by T. N. Baker, IOM, London, (1997), 44-64.

23) J. Kunze, C. Mickel, M. Leonhardt and S. Oswald: Steel Res., 68 (1997), 403-408.

24) T. Nakahara: CAMP-ISIJ, 11 (1998), 1301. 